\title{
NOVELTY SEEKING TO PREDICT TOURIST BEHAVIOR INTENTION IN RURAL DESTINATION
}

Submitted Date :

16 Maret 2020

Accepted Date :

15 Agustus 2020
Eny Endah Pujiastuti UPN "Veteran" Yogyakarta Enyendah04@gmail.com

\author{
Umar Nimran \\ Suharyono \\ Andriani Kusumawati \\ Universitas Brawijaya
}

\section{Suggested Citation :}

Assaker, G., Vinzi, V.E. and O'Connor, P., (2011). Examining the effect of novelty seeking, satisfaction, and destination image on tourists' return pattern: A two factor, non-linear latent growth model. Tourism Management, 32(4), pp.890-901

\begin{abstract}
Tourists' perceptions toward a destination image, novelty-seeking, tourist satisfaction, and behavior intention are vital for a successful destination marketing. The literature on travel and tourism reveals an abundance of studies on destination image, tourist satisfaction, and behavior intention even though their relationships with novelty-seeking have not been thoroughly investigated in the rural destination. Consequently, the aim of this study is to investigate the influence of destination image on novelty-seeking and satisfaction, which in turn affects the behavior intention of the tourist. The conceptual model was developed on the basis of theoretical and empirical research in the field of tourism; the empirical data were collected in a rural destination. A total of 380 questionnaires was returned and the data were analyzed by using SEM AMOS. The results showed that the destination image has a significant effect of novelty-seeking, satisfaction and behavior intention. Simultaneously, novelty-seeking has a significant effect on behavioral intention. Secondly, satisfaction has a significant effect on behavior intention. Several recommendations were also compiled for future studies.
\end{abstract}

Keywords: Destination image, novelty-seeking, satisfaction, behavior intention

\begin{abstract}
Abstrak
Persepsi wisatawan terhadap citra destinasi, pencarian hal baru, kepuasan wisatawan, dan niat perilaku sangat penting untuk pemasaran destinasi yang sukses. Literatur tentang perjalanan dan pariwisata mengungkapkan banyak studi tentang citra destinasi, kepuasan wisatawan, dan niat perilaku meskipun hubungannya dengan pencarian kebaruan belum diselidiki secara menyeluruh di daerah tujuan pedesaan. Oleh karena itu, tujuan dari penelitian ini adalah untuk mengetahui pengaruh citra destinasi pada pencarian kebaruan dan kepuasan, yang pada gilirannya mempengaruhi niat perilaku wisatawan. Model konseptual dikembangkan atas dasar penelitian teoritis dan empiris di bidang pariwisata; data empiris dikumpulkan di daerah tujuan pedesaan. Sebanyak 380 kuesioner dikembalikan dan data dianalisis dengan menggunakan SEM AMOS. Hasil penelitian menunjukkan bahwa citra destinasi memiliki pengaruh yang signifikan terhadap pencarian kebaruan, kepuasan dan niat berperilaku. Secara bersamaan, pencarian kebaruan memiliki efek signifikan pada niat perilaku. Kedua, kepuasan berpengaruh signifikan terhadap niat berperilaku. Beberapa rekomendasi juga dikumpulkan untuk studi selanjutnya.
\end{abstract}

Kata Kunci: Citra Destinasi, Kepuasan Wisatawan, Pencarian Kebaruan, Niat Perilaku

JEL Classification: Z32 


\section{Introduction}

The phenomenon that occurs in today's society is that every weekend and holiday, thousands of people leave their homes in the city to go to rural areas that have historical, architectural, cultural, scenic, or only community values with social interaction. The same behavior can be found in relation to the flow of tourists who traveled from more coastal or urban areas (either as tourists or excursionist) in which they are interested with the characteristic of such interest (Royo, 2009). This happens because the majority of tourism markets are in urban areas while the tourists often seek for a great experience and some destinations which are different from their everyday life (Silva et al., 2013). The changes on tourist behavior are because travelers want to get something different or novelty-seeking and want to get a unique experience after interacting with the destination. Lee and Crompton (1992) stated that this kind of behavior is driven by the motivation of tourists to meet the needs of novelty.

Therefore, the current tourism system starts to grow to the tourism that can provide a unique experience. Travelers who live in urban areas want to get a unique experience so that they go to the countryside. The growing destination at this time is a tourism village. The uniqueness of tourism village is not only as a place to enjoy the natural scenery and village life, but also as a means to interact directly with the villagers. Activities offered by the community as tourist attractions are real everyday life so that tourists can experience how life in the village. Rurality is seen as a central point of uniqueness and marketing in the package of rural tourism. Tourism activities such as a social interaction between tourists and the people in tourism village will eventually provide an experience (Mohamad et al., 2014). Travel experience becomes very important for rural areas so that the need to develop an attractive and typical tourism are essential for the pressing and heterogeneous tourism market (Loureiro, 2014).

The needs for a different experience have motivated the tourists to make changes in its behavior. Travelers have novelty-seeking in their mind in which it will affect the decision-making in choosing a destination. Therefore, noveltyseeking is considered as a key component of travel motivation (Crompton, 1979) and plays an important role in the decision-making of traveling (Petrick, 2002). By understanding novelty-seeking, that will help the tourists about their travel destination and intentions to a specific destination (Niininen et al., 2004). This can be linked to the results of Assaker et al., (2011) which stated that travelers who seek for a high novelty are rarely returned to the destinations that have been visited before, while on the other hand, those who seek a high familiarity (low novelty) tend to often go back to the same place. The analysis of changes in traveler behavior and travel motivations as well as the results from Assaker et al., (2011) showed that further research about the role of novelty-seeking with behavior intention is needed in the future. In the tourism industry, tourism managers are very important in ensuring travelers to re-visit the tourist attraction after they have experienced the first place (Osman and Santosa, 2013). Other than that, there is not much research in the field of tourism that uses novelty-seeking variables. Thus, the purpose of this paper is to show the relationship between the image of the destination with novelty-seeking, satisfaction, and behavior intention in the field of tourism, especially the tourism village and to test the conceptual model of research that is connected between the image of the destination, novelty-seeking, satisfaction and behavior intention.

\section{Literature review}

\section{Destination Image}

In the area of tourism destination marketing, an image has various definitions. The theorists of tourism management have defined images as sets of impressions, ideas, expectations, and emotional thoughts to maintain such a place (i.e. Assaker, 2014), which represents associations and pieces of information connected with a destination (Kotler, et al, 1993). The destination image is 'a set of beliefs, ideas, and impressions that people have in correlation with a place or destination' (Baloglu and McCleary, 1999). Most researchers also agree that the image of a destination is a set of impressions, ideas, expectations, and emotional thoughts an individual has of a specific place (Baloglu and McCleary, 1999; Beerli and Martin, 2004; Kim and Richardson, 2003).

Two main approaches are the ones developed by Echtner and Ritchie (1991) and Gartner (1993), with the latter being more popular among tourism scholars (Zhang et al., 2014). Gartner's (1993) approach postulates that the destination image consists of cognitive, affective and conative components. The cognitive image refers to an individual's perception, beliefs, and attitudes regarding the destination (Martin and Bosque, 2008; Qu, et al., 2011). Cognitive attributes may be functional/tangible (e.g. Landscape and cultural attractions) or psychological/abstract (e.g. Feelings of hospitality and atmosphere) (Martin and Bosque, 2008). The effective image is related to the feelings and emotions that a tourist destination evokes (Baloglu, 1999; Martin and Bosque, 2008). The conative component of destination image represents tourists' active consideration of a place as a potential travel destination (Gartner, 1993). Similarly, Bagozzi 
(1992) notes that "A person who finds an act appealing may have no desire to perform it and either may intend not to do it or may form no intention one way or the other", stressing the role of what an image connotes for intention to act.

The image of the destination has an important role in the decision-making process since all decision-making, such as the factor of money, time, and family are based on the image of each destination in which it is a motivation for the decision maker (Gartner, 1993). According to Crompton's (1992), in the theory of destination choice, tourists' decisionmaking is a sequential process that leads them to select a certain destination when they perceive that respective destination's attributes would satisfy their needs. If the tourists receive a positive destination image in their mind, then the tourists will be satisfied easily (Khan et al., 2013). The research on the relationship between destination image and novelty-seeking by Cheng and $\mathrm{Lu}$ (2015) explained that destination image is the key to awakening novelty and hedonics, and the influence of novelty itself is the most dominant factor. Cheng and Lu (2015) at that time have conducted a study on 355 Taiwan tourists with SEM analysis tool.

\section{Novelty Seeking}

Tourist motivation is recognized as a "global force" that gives value and direction to various choices and behaviors (Pearce et al., 1998). Among tourism-related motivations, novelty-seeking has been reported consistently as "a key motive" in the tourism context (Lee and Crompton, 1992). Novelty-seeking theory provides a strong theoretical foundation in explaining a destination choice behavior (Babu and Bibin 2004; Bello and Etzel 1985). Variety and novelty-seeking share the same conceptual foundation - that consumers seek optimal levels of stimulation, thus influencing their choice of behavior (Hebb and Thompson 1954). In the tourism context, variety seeking is replaced with novelty seeking which has an important relationship with tourist destinations (Jang and Feng, 2007). Novelty is often defined as the degree of contrast between present perception and past experience, making it the opposite of familiarity (Pearson, 1970). Faison (1977) defined novel travel as a trip characterized by new and unfamiliar experiences that differ from prior life experiences. Novelty-seeking plays an important role in understanding the tourist behavior and in influencing their intentions to return (Barroso, et al., 2007; Jang and Feng, 2007; Niininen et al., (2004).

The empirical research which examined the relationship between novelty-seeking and travelers' intention to revisit the destination are still limited. Novelty-seeking is actually a key role in understanding travel behavior and influenced the intentions to return to the same destination in the future (Barroso et al., 2007). Different results have been obtained by Assaker et al., (2011) that tourists who are looking for high level of novelty will rarely go back to the destinations which have been visited before while those who seek for high familiarity or low level of novelty were more likely to go back to the same place. Jang and Feng (2007) found that novelty-seeking has a positive influence on any intention of returning either direct or indirect (through satisfaction). The results of research conducted by Bigne et al., (2009) showed that novelty-seeking has a more significant effect on the intention to return rather than satisfaction. The understanding of novelty-seeking could help tourists to select their travel destinations and intentions to return to certain destinations (Niininen et al., 2004).

\section{Satisfaction}

In the tourism context, a research has suggested that tourist satisfaction is primarily a function of prior expectation and perceived performance following an experience (Chen and Chen, 2010; Chi and Qu, 2008). Within the customer behavior framework, Hunt (1977) broadly defines consumer satisfaction as a qualitative appraisal of the product experience against what it was supposed to be. Within the discipline of tourism, satisfaction has been defined as an outcome of the tourist' experience in a destination compared against their expectations about the visit (Pizam et al.,1978). Oliver (1997) also defined satisfaction as "the consumer's fulfillment response" and "a judgment that a product or service feature, or the product or service itself, provides a pleasurable level of consumption-related fulfillment". Although customer satisfaction, following this last perspective, Bosque and Martin (2008) define satisfaction as 'an individual's cognitive-affective state derived from a tourism experience'.

Munhurrun et al., (2015) in his research mentioned the relationship between destination image and satisfaction. In line with that, Pratminingsih et al., (2014) found that destination image has a positive effect on satisfaction. Previous research from Mohamad et al., (2014), Assaker and Hallak (2013), Khan et al., (2013), Assaker et al., (2011), Chen and Phou (2013), Tavitiyaman and Qu (2013), Prayag (2009, Chi Dan Qu (2008) also has identified a positive relationship between destination image and satisfaction. Kozak and Rimmington (2000) said that a better destination image will give satisfaction to certain destinations. However, contradictory findings by Chen and Tsai (2007) revealed that destination image does not affect satisfaction. 
The research results from Prayag et al., (2013) proved that satisfaction has a positive relationship with behavior intention. Furthermore, Cole et al., (2002) believed that there is a good association in between satisfaction and behavior intention in the scope of tourism. Bolton and Drew (1991) stated in the context of tourism that a high level of satisfaction and positive destination image may lead to positive behavior towards destinations in the future. Besides that, other research also supports these findings as for an example is the research of Tavitiyaman and Qu (2013).

\section{Behavior Intention}

The modeling behavior intention remains an important topic in tourism marketing and tourism research. Studies of tourists' behavior intention mainly focus on two topics, destination choice intention (Lam and Hsu 2006) and post-purchase behavior intention (Kozak 2002), with the latter receiving the majority of attention. Favorable behavior intention represents conative loyalty (Chen and Chen, 2010). Behavior intention is defined as an individual's anticipated or planned future behavior (Oliver and Swan 1989), it represents the expectations of a particular form of behavior in a given setting and can be operationalized as the likelihood to act (Fishbein and Ajzen 1975). Behavior intentions, according to Zeithaml et al., (1996) is the willingness to recommend the service to others and is the intention to repurchase (behavior intention). Oliver (1999) described behavior intention as an attitude towards purchasing a product on the basis of previous experience, and this attitude strongly relates to consumers' intentions to repurchase or to recommend the service or product to others.

Zeithaml et al. (1996) suggested that a favorable behavior intention is associated with a service provider's ability to get its customers to say positive things about them, recommend them to other customers, remain loyal to them (i.e. Repurchase from them), spend more with them, and pay premium prices. Cole and Illum (2006) stated that behavior intention consists of Say positive things about the destination and revisit the destination in the future. In recent studies, behavior intentions have usually been explored within the cognitive-affective-conative framework (e.g. Lam et al. 2004; Oliver 1999), which is theoretically justified by Bagozzi's (1992) self-regulatory mechanism model.

Moon et al., (2013) has examined that destination image is positively related to consumer behavior or intention. Gallarza and Saura (2006) also suggested several primary factors of behavior intention such as satisfaction, expectation, perceived quality, and destination image. Destination image may affect the tourist satisfaction and behavior such as destination selection, next evaluation, and future behavioral intentions (Bigne et al. 2001). The destination image and satisfaction are two important variables which influence the behavior intention of the tourists (Chen and Tsai, 2007). On the other hand, Court and Lupton (1997) found that a positive destination image could influence tourist intentions to review their destinations in the future.

\section{Hypotheses}

Based on the literature review, the hypotheses of this study are:

1). $H_{1}$ : destination image has a significant effect on novelty-seeking

2). $\mathrm{H}_{2}$ : destination image has a significant effect on satisfaction

3). $\mathrm{H}_{3}$ : destination image has a significant effect on behavior intention

4). $\mathrm{H}_{4}$ : novelty-seeking has a significant effect on behavior intention

5). $\mathrm{H}_{5}$ : satisfaction has a significant effect on behavior intention

\section{Research Method}

Although not many studies have examined the effect of novelty-seeking towards behavior intention, the study on the influence of destination image, novelty-seeking, and satisfaction towards behavior intention in tourism village was still conducted. The purpose of this study was to test whether the destination image, novelty-seeking, and satisfaction could affect the behavior intention.

\section{Survey instrument}

The variables which were observed consisted of 4 variables such as destination image, novelty-seeking, satisfaction, and behavior intention. There are 24 items which include the measurement of exogenous independent variables such as 6 items of the destination image, 6 items of novelty-seeking, 6 items of satisfaction, and 6 items of behavior intention (endogenous). The scaling applied in this study is the 5-point Likert scale of 1-strongly agree, 2-agree, 3-neutral, 4disagree, and 5-strongly disagree. The demographics variables questioned are gender, age, status, and education background of the respondents. 


\section{Sample}

The sample used in this study were tourists who were visiting the tourism village of Pentingsari, Pulesari, Grogol, Brayut, Kelor, Sleman, Yogyakarta. The sampling technique used was accidental sampling with the selected samples of tourists who have the characteristics of staying at least one day, aged between 18-35 years, had visited the place one time, and choose the destinations by its initiative; the sample used in this study were as many as 380 tourists.

\section{Data analysis}

In this research, an inferential statistic will be used to test the effect of destination image and customer experience toward trust and behavior intention. The SEM AMOS was used for the inferential statistic. The results of this examination were calculated by using SPSS for Windows version 22.

\section{Result}

Validity test between the variable construct of destination image, novelty-seeking, satisfaction and post behavior intention and Confirmatory Factor Analysis (CFA) is as follows:

Table 1. The Results of Confirmatory Factor Analysis

\begin{tabular}{|c|c|c|}
\hline Variable & Items & Loading Factor \\
\hline \multirow{4}{*}{ Destination image } & DI1 & 0,727 \\
\cline { 2 - 3 } & DI2 & 0,796 \\
\cline { 2 - 3 } & DI3 & 0,777 \\
\cline { 2 - 3 } & DI4 & 0,775 \\
\cline { 2 - 3 } & DI5 & 0,792 \\
\hline Novelty seeking & DI6 & 0,700 \\
\cline { 2 - 3 } & NS1 & 0,768 \\
\cline { 2 - 3 } & NS2 & 0,781 \\
\cline { 2 - 3 } & NS3 & 0,798 \\
\cline { 2 - 3 } & NS4 & 0,766 \\
\cline { 2 - 3 } & NS5 & 0,731 \\
\hline \multirow{4}{*}{ Satisfaction } & NS6 & 0,822 \\
\cline { 2 - 3 } & KEP1 & 0,812 \\
\cline { 2 - 3 } & KEP2 & 0,820 \\
\cline { 2 - 3 } & KEP3 & 0,779 \\
\cline { 2 - 3 } & KEP4 & 0,831 \\
\cline { 2 - 3 } & KEP5 & 0,845 \\
\cline { 2 - 3 } & KEP6 & 0,823 \\
\hline \multirow{4}{*}{ post behavior intention } & PBI1 & 0,821 \\
\cline { 2 - 3 } & PBI2 & 0,815 \\
\cline { 2 - 3 } & PBI3 & 0,829 \\
\cline { 2 - 3 } & PBI4 & 0,790 \\
\cline { 2 - 3 } & PBI5 & 0,813 \\
\hline \multirow{4}{*}{} & PBI6 & 0,856 \\
\hline
\end{tabular}

Source: Output AMOS 22 Confirmatory Factor Analysis, 2019

According to the data in table 1 , it can be known that all the indicators which measure the variables of the destination image, novelty-seeking, satisfaction, and behavior intention has produced a loading factor that is greater than 0,6 . Thus, the indicators that measure the variables of the destination image, novelty-seeking, satisfaction, and behavior intention can be declared to be valid or able to measure those variables. 
Table 2. Construct Reliability Test

\begin{tabular}{|l|c|c|}
\hline Variable & Construction reliability & Description \\
\hline Destination Image & 0,8923 & Reliable \\
\hline Novelty-seeking & 0,9019 & Reliable \\
\hline Satisfaction & 0,9241 & Reliable \\
\hline Behavior Intention & 0,9253 & Reliable \\
\hline
\end{tabular}

Therefore, it can be concluded that the latent construct of the image of the goal of high reliability, the search for novelty, satisfaction, and post-behavioral intentions have high reliability with the same construct reliability value 0.70 which is mandatory good

Table 3 presents the result of the goodness of fit for the full model developed using cut-off value:

Tabel 3

Goodness of Fit Index

\begin{tabular}{|c|c|c|c|}
\hline Goodness of fit index & Cut-off value & Research Model & Model \\
\hline Chi Square Statistic & Required small & 280,850 & \\
\hline Probability & $\geq 0.05$ & 0,068 & Good Fit \\
\hline RMSEA & $\leq 0.08$ & 0,019 & Good Fit \\
\hline GFI & $\geq 0.90$ & 0,943 & Good Fit \\
\hline AGFI & $\geq 0.90$ & 0,931 & Good Fit \\
\hline CMIN/DF & $\leq 2.0$ & 1,137 & Good Fit \\
\hline TLI & $\geq 0.90$ & 0,994 & Good Fit \\
\hline CFI & $\geq 0.90$ & 0,995 & Good Fit \\
\hline
\end{tabular}

Source: Output AMOS 22 Model Fit Summary, 2018

The whole result of the goodness of fit shows a good level of suitability. Thus, it can be said that the results of the goodness of fit testing on the standard model indicate that the data is following the theory or model. The model of the test results is as follows:

Figure 1

Full Model Structural Equation Modeling

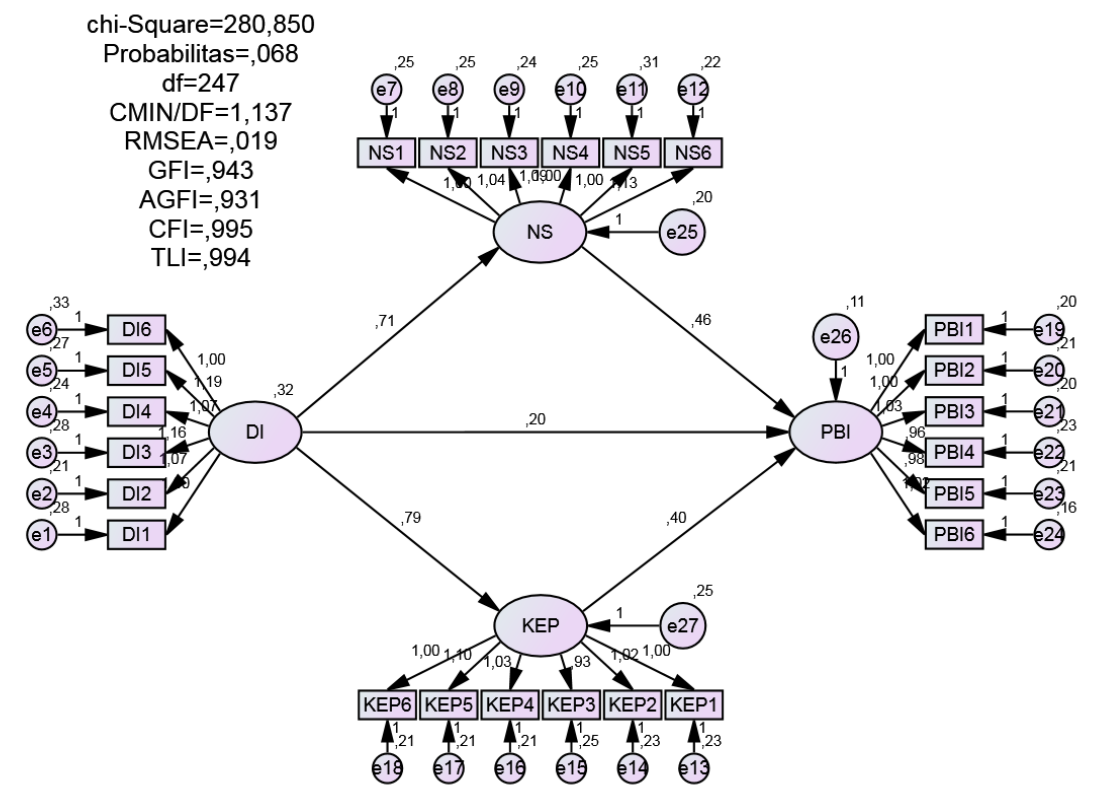

Source : Output AMOS 22 Full Model, 2019

The testing of the seven hypotheses is based on the value of the critical ratio (CR) of a causal relationship. 
Table 4 Causality test

\begin{tabular}{|c|c|c|c|c|c|c|}
\hline \multicolumn{2}{|c|}{} & \multicolumn{1}{|c|}{ Estimate } & S.E. & C.R. & P \\
\hline NS & $<---$ & DI &, 707 &, 066 & 10,673 & 0,000 \\
\hline KEP & $<---$ & DI &, 789 &, 071 & 11,054 & 0,000 \\
\hline PBI & $<---$ & DI &, 199 &, 066 & 3,024 & 0,002 \\
\hline PBI & $<---$ & NS &, 456 &, 058 & 7,868 & 0,000 \\
\hline PBI & $<---$ & KEP &, 400 &, 050 & 7,962 & 0,000 \\
\hline
\end{tabular}

From the table above, the test results are intepreted as follows:

a. Hypothesis 1 Testing

The $C R$ value of the parameter estimation for the impact testing of destination image on novelty seeking is 10.673 with a probability of 0.000 , so its significance $<0.05$. Therefore, the hypothesis which says destination image has a significant effect on novelty-seeking has been proven.

b. Hypothesis 2 Testing

The CR value of the parameter estimation for the impact testing of destination image on satisfaction is 11.054 with a probability of 0.000 , so its significance $<0.05$. Therefore, the hypothesis which says destination image has a significant effect on satisfaction has been proven.

c. Hypothesis 3 testing

The CR value of the parameter estimation for the impact testing of destination image on post behavior intention is 3.024 with a probability of 0.000 , so its significance $<0.05$. Therefore, the hypothesis which says destination image has a significant effect on post behavior intention has been proven.

d. Hypothesis 4 Testing

The CR value of the parameter estimation for the impact testing of novelty-seeking on behavior intention is 7.868 with a probability of 0.000 , so its significance $<0.05$. Therefore, the hypothesis which says novelty-seeking has a significant effect on post behavior intention has been proven.

e. Hypothesis 5 Testing

The $C R$ value of the parameter estimation for the impact testing of dsatisfaction on post behavior intention is 7.962 with a probability of 0.000 , so its significance $<0.05$. Therefore, the hypothesis which says satisfaction has a significant effect on post behavior intention has been proven.

The mediation relationship between the independent variables and the dependent variable can be seen by comparing the value of standardized direct effects and the standardized indirect effects. This means if the value of the standard direct effects is smaller than the value of the standardized indirect effects, the mediating variable has an indirect effect on the relationship between the two variables.

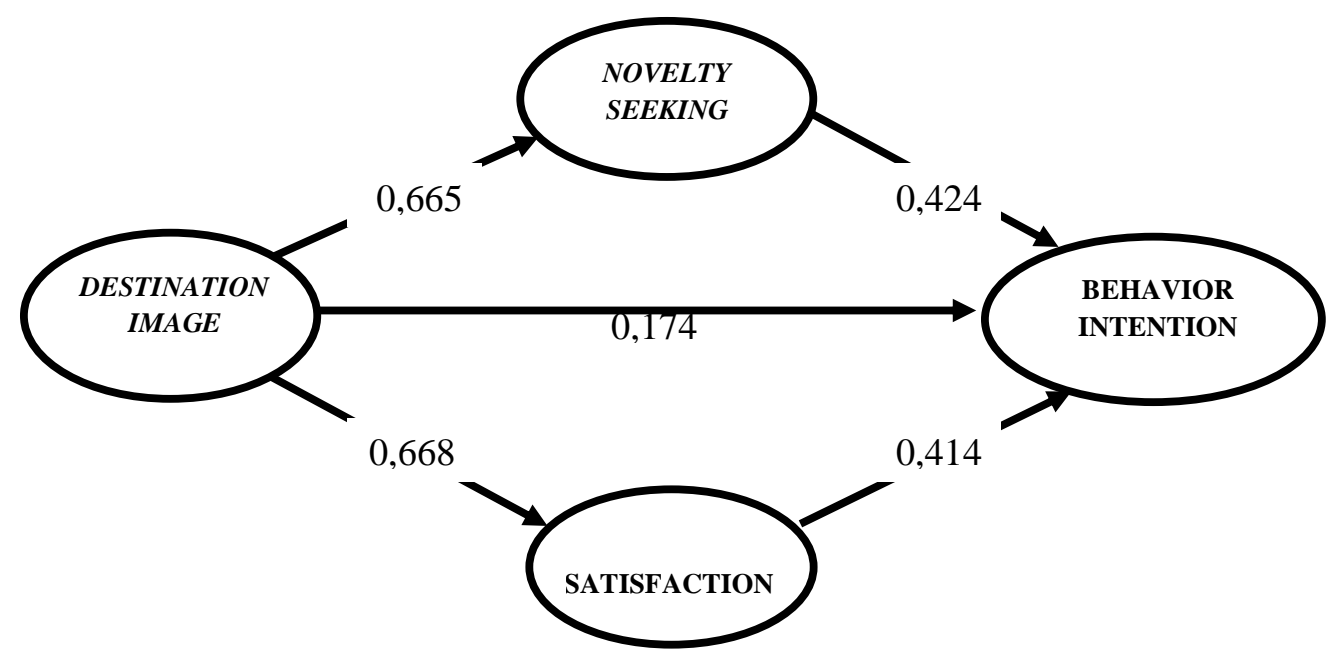

Figure 2

Path Analysis 
The mediation relationship between the independent variables and the dependent variable can be seen by comparing the value of standardized direct effects and the standardized indirect effects. This means if the value of the standardized direct effect is smaller than the value of the standardized indirect effect, the mediating variable has an indirect effect on the relationship of those two variables.

a. The results of the path analysis showing the indirect effect of destination image on behavior intention through novelty seeking are as follows:

$\mathrm{DI} \rightarrow \mathrm{NS} \rightarrow \mathrm{BI}=0.665 \times 0.424=0.28196$

Description:

$\mathrm{DI}$ : destination image

NS : novelty seeking

$\mathrm{BI}$ : behavior intention

The results of the path analysis show that the indirect effect of destination image on behavioral intention through novelty seeking is 0.28196 . This shows that the indirect effect is greater than the direct effect of 0.174 . Therefore, novelty seeking can mediate destination image of behavior intention positively.

b. The results of the path analysis showing the indirect effect of destination image on behavior intention through novelty seeking are as follows:

$\mathrm{DI} \rightarrow \mathrm{SA} \rightarrow \mathrm{Bl}=0,668 \times 0,414=0,276552$

Description:

DI : destination image

SA : satisfaction

$\mathrm{BI}$ : behavior intention

The results of the path analysis show that the indirect effect of destination image on behavioral intention through satisfaction is 0.276552 . This shows that the indirect effect is greater than the direct effect of 0.174 . Therefore, satisfaction can mediate destination image of behavior intention positively.

\section{Discussion}

The results showed that destination image has a positive and significant impact on novelty-seeking. The results of this study also support previous research conducted by Cheng and Lu (2013) which points out the relationship between destination image and novelty-seeking. In their research, it is found that destination image has a significant influence on novelty. The destination image is actually a key to awaken novelty. The results of this study are in line with the opinion of Zuckerman (1971) that if tourists can fill their expectations from the desired destination, then they will rate it as a new and hedonist location. Gartner (1993) asserted that when tourists feel the image destination can provide motivation and experience like knowledge and adventure, they will feel novelty-seeking and pleasure in which they will choose to visit the destination. The results of this study confirm that a good destination image of consumers is one important factor that encourages the emergence of novelty-seeking.

The results also show that destination image could positively and significantly influence tourist satisfaction. If tourists receive a positive image for each destination in their mind, they will be satisfied with ease. The results of this study indicate that, when the tourists enjoy the tourism village and the information previously submitted similar to those in the village, they will certainly experience such satisfaction. The satisfaction of tourists will increase if the destination has a positive image. The results support the research from Munhurrun et al., (2015) which argues that destination image has a significant and positive influence on satisfaction; the higher the destination image, the higher the satisfaction of tourists. The results of Assaker and Hallak (2013) underlined that destination image gives a positive impact on satisfaction. Those all also support the research that has been done by Mohamad et al., (2014), Pratminingsing et al., (2014), Assaker et al., (2011), Chen and Phou (2013), Tavitiyaman and Qu (2013). However, the results of this study are contradictory to the research conducted by Chen and Tsai (2007) which said that a destination image has no effect on satisfaction.

Chi and Qu (2008) affirmed that there are many factors that lead to tourist satisfaction but the image of a tourist destination is one significant factor. Customer satisfaction and long-term behavior intention are influenced by emotions while enjoying the service. If tourists have a positive image for each destination in their minds, then tourists will be satisfied easily (Khan et al.,2013). Furtherly, the implications of the study confirm that a good destination image of consumers is one important factor which led to consumers' satisfaction. 
On the other hand, several studies showed that destination image has a positive but not significant effect on behavior intention in which this means that even though tourists have a positive image of the tourism village previously, it will not automatically guarantee to encourage the next behavior in the future. The results have confirmed the results of research conducted by Jin et al., (2013) and Wang and Hsu, (2010). Jin et al., (2013) suggested that there is no effect between destination image on behavior intention while Wang and Hsu (2010) stated that destination image does not have a direct influence on behavior intention. Nevertheless, the results of these studies are empirically different from Moon et al., (2013) that destination image of consumers is positively correlated with behavior intention. These differences can also be found in the research of Gallarza and Saura (2006) that the primary factors of behavior intention (postpurchase) consist of satisfaction, expectation, perceived quality, and destination image. This also significantly differ from the research of Bolton and Drew (1991) that in the context of tourism, high level of satisfaction and positive destination image may lead to positive behavior towards destinations in the future.

An analysis of destination image variable that is not significantly affected behavior intentions can be explained as follows: if it is analyzed in terms of the respondent characteristic that is the first visitation, the destination image that can be required is the destination image (of tourism village) from the internet and other promotional media. By that, tourists seem to only have a knowledge in the mind and do not get any effective responses that will build an emotional bond between the tourists with the village. Therefore, the tourist could not use the services or enjoy the tour to the fullest because they do not have an emotional attachment which able to bring the behavior intention in the future. If the results of this study are associated with Bagozzi's theory (1992) in correlation with a cognitive appraisal - affective response behavioral responses, it is known that cognitive appraisal can not directly produce - behavioral response for future purchases (repeatedly). However, it must pass the process of cognitive appraisal - affective response - behavioral response. This means that cognitive appraisal should be internalized within ourselves so that we could have an emotional attachment (affective response) in which it will generate behavior intention in the future. This proves that destination image (cognitive appraisal) has no significant effect on behavior intention (behavioral response) in the future; it must go through an affective response that can lead to behavior intention. The analysis of this study is consistent with Tavitiyaman and Qu (2013) which stated that destination image alone can not directly encourage the behavior intention in the future.

Furthermore, the results showed that novelty-seeking is influenced the behavior intention positively and significantly. This confirmed the research conducted by Jang and Feng (2007) which found that novelty-seeking has a positive influence on behavior intention to return either directly and indirect (through satisfaction). Bigne et al., (2009) also showed that novelty-seeking had more significant effect on behavior intention rather than satisfaction. It is actually similar with those expressed by (Babu and Bibin, 2004) that the desire for novelty-seeking (looking for new experiences and new tourist destinations) can play an important role in explaining the tourists' intention to return to the site; in spite of the level of satisfaction and destination image. The results of this research are contrary to the research conducted by Assaker et al., (2011) which believed that travelers who seek for a high novelty are rarely returned to the destinations that have been visited before, while on the other hand, those who seek a high familiarity (low novelty) tend to often go back to the same place. This also in contrast with the results expressed by Bello and Etzel (1985) that a tourist who has noveltyseeking will demonstrate a lower likelihood to return to the same destination.

Other than that, the analysis showed that satisfaction has no significant but positive effect on behavior intention. This is similar to the research of Prayag (2009), that satisfaction does not have an influence on behavior intention. The results of this study showed different indications with the research conducted by Munhurrun et al., (2015), Tavitiyaman and Qu (2013), Prayag et al., (2013), Jin et al., (2013). Prayag et al., (2013) in his research mentioned that satisfaction has a positive relationship to behavior intention. Tavitiyaman and Qu (2013) also stated that the positive perception of destination image of a particular destination is important to improve the overall satisfaction and behavior intention. Furthermore, Jin et al., (2013) expressed that satisfaction is able to influence behavior intention. The results of this study are also different from the research conducted by Reichheld and Sasser (1990), that customer satisfaction significantly affected behavior intention in the future. Munhurrun et al., (2015) also have different ideas that the level of satisfaction is important to create a positive behavior intention in the future. What is meant by behavior intention is similar to what have been submitted by Fornell (1992) that behavior intention is the desire to go back to the same destination and more willing to share their positive travel experience with their friends and family.

The results showed that satisfaction does not affect the behavior intention in the future in which this can be explained as follows: tourists who are satisfied with their vacation do not have the behavior intention to go back again in the future because there are many alternatives of destination so that they can seek new experiences rather than repeat the experience from the past. Kahn (1995) suggested that the search for an alternative destination will probably be 
influenced by the level of variety seeking. Tourists or travelers who are satisfied with the holidays but chose not to return to the same destination are as a result of things that happen outside the destination (e.g delayed flights or problems with the travel agency) (Goodall, 1990). Keaveney (1995) and Reichheld (1993) said that particular customers will switch the product and make a new purchase although a satisfaction has been obtained before. Garcia et al., (2012) believed that even though the tourists are satisfied and have no regrets about their choice, they are able to switch to another product.

\section{Conclusion}

This work analyzes the influence of the destination image, novelty seeking, satisfaction, and behavior intention in future on rural destination. The most prominent findings from this study are that destination image has no significant but positive effect on behavior intention and, secondly, satisfaction has positive and no significant impact on behavior intention. The other findings from this study indicate that the destination image has a positive and significant impact on novelty-seeking and on satisfaction while novelty-seeking delivers a positive and significant effect on behavior intention.

The main contribution of this paper is to consider the issue of changes in tourist behavior in the context of behavior intention study and also a specific analysis of novelty-seeking. The findings are considered to offer new insight into the role of novelty-seeking on behavior intention. However, this subject requires additional research to improve the understanding of novelty-seeking role on behavior intention. In this study, the variable of destination image involves a variable of destination personality, although in some other studies destination personality is used as a different variable. Therefore, a separation of the variable will produce different results and may be better on portraying the destination image. Finally, it is proposed that the next research could develop the existing model by using a variable of destination image and destination personality that can illustrate the intact destination image.

\section{References}

Assaker, G., Vinzi, V.E. and O'Connor, P., (2011). Examining the effect of novelty seeking, satisfaction, and destination image on tourists' return pattern: A two factor, non-linear latent growth model. Tourism Management, 32(4), pp.890901

Assaker, Guy and Rob Hallak. (2013). Moderating Effects of Tourists' Novelty-Seeking Tendencies on Destination Image, Visitor Satisfaction, and Short- and Long-Term Revisit Intentions, Journal of Travel Research 52(5), 600-613

Assaker, G, (2014), Examining a hierarchical model of Australia's destination image, Journal of vacation marketing, 20(3), $195-210$

Babu, P. G., and P. G. Bibin. (2004). Past Visits and the Intention to Revisit a Destination: Place Attachment as the Mediator and Novelty Seeking as the Moderator. Journal of Tourism Studies, 15: 51-66

Bagozzi, R. P. (1992). The self-regulation of attitudes, intentions and behavior. Social Psychology Quarterly, 55,178-204.

Baloglu, S., and McCleary, K. W. (1999). A model of destination image formation. Annals of Tourism Research, 26, 868897

Barroso, C., E. Martin, and D. Martin. (2007). "The Influence of Market Heterogeneity on the Relationship between a Destination's Image and Tourists' Future Behavior." Tourism Management, 28: 175-87.

Beerli, A., and Martın, J. D. (2004). Factors influencing destination image. Annals of Tourism Research, 31(3), 657-681.

Bello, D.C. and Etzel, M.J. (1985). The Role of Novelty in the Pleasure Travel Experience. Journal of Travel Research, 24(1), pp.20-26

Bigne, J.E., Sanchez, M.I. and Sanchez, J.. (2001). Tourism image, evaluation variables and after purchase behaviour: inter-relationship. Tourism Management, 22, pp.607-616.

Bigne, J. E., M. I. Sanchez, and L. Andreu. (2009). "The Role of Variety Seeking in Short and Long Run Revisit Intentions in Holiday Destinations." International Journal of Culture, Tourism and Hospitality Research, 3: 103-15.

Bolton, R., and J. Drew. (1991). "A Multistage Model of Customer Assessment of Service Quality and Value." Journal of Consumer Research, 17: 375-84.

Chen, C.-F., and Chen, F.-S. (2010). Experience quality, perceived value, satisfaction, and behavioral intentions for heritage tourists. Tourism Management, 31,29-35. 
Chen, C.-F. and Phou, S.(2013). A closer look at destination: Image, personality, relationship and loyalty. Tourism Management, 36, pp.269-278.

Chen, C.-F. and Tsai, D. (2007). How destination image and evaluative factors affect behavioral intentions? Tourism Management, 28(4), pp.1115-1122.

Cheng, Tien-Ming and Lu, Chiang-Chuan, (2015), Destination Image, Novelty, Hedonics, Perceived Value, and Revisiting Behavioral Intention for Island Tourism, Asia Pacific Journal of Tourism Research, 18:7, 766-783

Chi, C.G.-Q. and Qu, H. (2008). Examining the structural relationships of destination image, tourist satisfaction and destination loyalty: An integrated approach. Tourism Management, 29(4), pp.624-636.

Chou, Hsu-Jung. (2013). The Effect of the Visitor's Consumption Experience and Tourism Image on Tourist Satisfaction and Revisit Intention of Taiwan's Night Markets. International Journal on Business Review.Vol 3,no 1,Nov,pp 129134

Cole, S.T; Crompton, J.L., and Willson, V.L. (2002). An empirical investigation of the relationships between service quality, satisfaction and behavioral intentions among visitors to a wildlife refuge. Journal of Leisure Research, 34(1), 1-24

Cole, S.T., and Illum, S.F. (2006). Examining the mediating role of festival visitors' satisfaction in the relationship between service quality and behavioral intentions. Journal of Vacation Marketing, 12(2), 160-173

Court, B., and Lupton, R. A. (1997). Customer portfolio development: modelling destination adopters, inactives and rejecters. Journal of Travel Research, 36(1), 35-43

Crompton, J.L., (1979). An Assessment of the Image of Mexico as a Vacation Destination and the Influence of Geographical Location Upon That Image. Journal of Travel Research, 17(4), pp.18-23.

Echtner,C.M and R. B. Ritchie,(1991).The Meaning and Measurement of Destination Image, The Journal of Tourism Studies, vol. 2, no. 2, pp. 2-12.

Faison, E. (1977). The neglected variety drive: a useful concept for consumer behavior. Journal of Consumer Research, 4,172-175.

Fishbein and Ajzen. (1975). Belief, Attitude, Intentions and Behavior: an introduction to theory and research. California: Addison-Wesley Publishing Company, Inc

Gallarza, M.G., and Saura, I.G. (2006). Value Dimensions, Perceived Value, Satisfaction and Loyalty: An Investigation of University Students' Travel Behaviour. Tourism Management, 27(3), 437-452.

García, I. S., R. Pieters, M. Zeelenberg, and J. E. Bigné. (2012). When Satisfied Consumers Do Not Return: Variety Seeking's Effect on Short- and Long-Term Intentions. Psychology and Marketing, 29: 15-24

Gartner, W. (1993). Image formation process. Journal of Travel and Tourism Marketing, 2(2/3), 191-215

Hebb, D. O., and W. R. Thompson. (1954). Handbook of Social Psychology. Reading, MA: Addison-Wesley.

Hunt, K, (1977), Conceptualizition and measurement of consumer satisfaction and dissastifaction, Cambridge, Marketing Science Institute

Hwang, H.; Malhotra, N. K.; Kim, Y.; Tomiuk, M. A., and Hong, S.(2010). A comparative study on parameter recovery of three approaches to structural equation modeling. Journal of Marketing research, 47(4), 699-712.

Jang, S. and Feng, R. (2007).Temporal destination revisit intention: the effects of novelty seeking and satisfaction, Tourism Management, Vol. 28, pp. 580-90.

Jin, Naehyun, Sangmook Lee and Hyuckgi Lee. (2013) : The Effect of Experience Quality on Perceived Value, Satisfaction, Image and Behavioral Intention of Water Park Patrons: New versus Repeat Visitors, International Journal of Tourism Research, 17:82-95 (2015) 
Keaveney, S. M. (1995). Customer Switching Behaviour in Service Industries: An Exploratory Study. Journal of Marketing, 59 (April): $71-82$

Khan, Abdul Highe; Ahasanul Haque and Muhammad Sabbir Rahman. (2013). What Makes Tourists Satisfied? An Empirical Study on Malaysian Islamic Tourist Destination, Middle-East Journal of Scientific Research 14 (12): 1631-1637

Kim,H and Richardson, s, (2003), Motion Picture Impact on Destination Image, Annal of Tourism Research, 30 (1), 216237

Kotler, Haider, and Rein, (1993), Marketing place: Attracting investmen industry and tourism to cities, states and nations, New York,Free Press

Kozak, M., and M. Rimmington. (2000). Tourist Satisfaction with Mallorca, Spain, as an Off-Season Holiday Destination. Journal of Travel Research, 38: 260-69.

Lam, S. Y., Shankar, V., Erramilli, M. K., and Murthy, B. (2004), "Customer Value, Satisfaction, Loyalty, and Switching Costs: An Illustration From a Business-to-Business Service Context,_Journal of the Academy of Marketing Science, 32(3), 293-311

Lee, T.-H. and Crompton, J., (1992). Measuring Novelty In Tourism Seeking. . Annual Of Tourism Research, 19, pp.732751.

Loureiro, Sandra Maria Correia,(2014), The role of the rural tourism experience economy in place attachment and behavioral intentions, International Journal of Hospitality Management 40 (2014) 1-9

Mitchell, V. W.and Vassos, V. (1997). Perceived risk and risk reduction in holiday purchases: A cross-cultural and gender analysis. Journal of Euro-Marketing, 6(3), 47-79.

Mohamad, Mahadzirah; Nur Izzati Ab Ghani; Mustafa Mamat and Ibrahim Mamat.(2014). Satisfaction as a Mediator to the Relationships Between Destination Image and Loyalty, World Applied Sciences Journal, 30 (9): 1113-1123.

Moon, Kae-Sung; Yong Jae Ko; Daniel P. Connaughton and Jeoung-Hak Lee. (2013). A mediating role of destination image in the relationship between event quality, perceived value, and behavioral intention, Journal of Sport \& Tourism, 18:1, 49-66,

Munhurrun, P. Ramseook; V.N. Seebaluck, and P. Naidoo.(2015). Examining the structural relationships of destination image,perceived value, tourist satisfaction and loyalty: case of Mauritius, Procedia - Social and Behavioral Sciences, 175 ( 2015) $252-259$

Niininen, O., Szivas, E. and Riley, M., (2004). Destination loyalty and repeat behaviour: an application of optimum stimulation measurement. International Journal of Tourism Research, 6(6), pp.439-447.

Oliver, R. L. (1997). Satisfaction: To Behavioral Perspective on the Customer (New York, NY, USA.: McGraw-Hill).

Oliver, R., and J. Swan. (1989). Consumer Perceptions of Interpersonal Equity and Satisfaction in Transactions: A Field Survey Approach, Journal of Marketing, 53 (2), 21-35.

Osman, Zahir and Ilham Sentosa. (2013). A study of mediating effect of trust on customer satisfaction and customer loyalty relationship in Malaysian rural tourism, European Journal of Tourism Research 6(2), pp. 192-206.

Pearson, P. H. (1970). Relationship between global and specified measures of novelty seeking. Journal of Consulting and Clinical Psychology, 34,199-204

Pearce, P. L., Morrison, A., and Rutledge, J. (1998). Tourism: Bridges across continents. Sidney: McGraw-Hill.

Petrick, J.F., (2002). An examination of golf vacationers' novelty. Annals of Tourism Research, 29(2), pp.384-400.

Pizam, A., Neuman, Y. and Reichel, A. (1978). Dimensions of tourist satisfaction with destination area, Annals of Tourism Research, Vol. 5 No. 3, pp. 314-322.

Pratminingsih, Sri Astuti ; Christina Lipuringtyas Rudatin and Tetty Rimenta. (2014). Roles of Motivation and Destination Image in Predicting Tourist Revisit Intention: A Case of Bandung - Indonesia, International Journal of Innovation, Management and Technology, Vol. 5, No. 1, February. 
Prayag, G. (2009). Tourists' Evaluations of Destination Image, Satisfaction, and Future Behavioral Intentions-the Case of Mauritius. Journal of Travel \& Tourism Marketing, 26(8), pp.836-853.

Prayag, G., Hosany, S. and Odeh, K. (2013). The role of tourists' emotional experiences and satisfaction in understanding behavioral intentions. Journal of Destination Marketing \& Management, 2(2), pp.118-127.

Reichheld, F. (1993). Loyalty-Based Management. Harvard Business Review, 71: 64-73

Reichheld, F., and Sasser, W.E. (1990). Zero defections: quality comes to services. Harvard Business Review, 68, 105111.

Royo-Vela, M., (2009). Rural-cultural excursion conceptualization: A local tourism marketing management model based on tourist destination image measurement. Tourism Management, 30(3), pp.419-428.

Silva, C., Kastenholz, E. dan Abrantes, J.L., (2013). Place-attachment, destination image and impacts of tourism in mountain destinations. Anatolia, 24(1), pp.17-29.

Sonmez, S., and Graefe, A. (1998). Influence of terrorism risk on foreign tourism decisions. Annals of Tourism Research, 25(1), 112-144.

Tang, Mei-Ling. (2014).Tourist Attraction, Satisfaction, and Behavioral Intention of Industrial Tourist: Economic Factors as Moderator, The Journal of International Management Studies, Volume 9 Number 2, August,

Tavitiyaman, Pimtong and Hailin Qu. (2014). Destination Image and Behavior Intention of Travelers to Thailand: The Moderating Effect of Perceived Risk, Journal of Travel \& Tourism Marketing, 30:169-185

Wang, C. Y., and Hsu, M. K. (2010). The relationships of destination image, satisfaction, and behavioral intentions: An integrated model. Journal of Travel \& Tourism Marketing, 27(8), 829-843.

Zang,H,Fu, X, Chai,L,A,dan Lu, L,(2014) Destination Image and Tourist Loyalty : Meta-analysis, Tourism Management, 40, 212-223

Zeithaml, V.a.; Berry, L.L. and Parasuraman, a. (1996). The Behavioral Consequences of Service Quality. Journal of Marketing, 60(2), p.31.

Zuckerman, M. (1971). Dimensions of sensation seeking. Journal of Consulting and Clinical Psychology, 36,45-52. 